\title{
The influence of fire on the assemblage structure of foraging birds in grasslands of the Serra da Canastra National Park, Brazil
}

\author{
MATHEUS G. REIS ${ }^{1,2}$, CAROLLINE Z. FIEKER ${ }^{1,2}$ and MANOEL M. DIAS ${ }^{2}$ \\ ${ }^{1}$ Pós-Graduação em Ecologia e Recursos Naturais, Universidade Federal de São Carlos/UFSCar, \\ Campus São Carlos, Rodovia Washington Luís, Km 235, 13565-905 São Carlos, SP, Brasil \\ ${ }^{2}$ Laboratório de Ecologia e Conservação de Aves Neotropicais, Departamento de Ecologia e Biologia Evolutiva, Universidade \\ Federal de São Carlos/UFSCar, Campus São Carlos, Rodovia Washington Luís, Km 235, 13565-905 São Carlos, SP, Brasil
}

Manuscript received on March 5, 2015; accepted for publication on July 6, 2015

\begin{abstract}
Grasslands are the most threatened physiognomies of the Cerrado biome (Brazilian savanna), a biodiversity hotspot with conservation as a priority. The Serra da Canastra National Park protects the most important remnants of the Cerrado's southern grasslands, which are under strong anthropogenic pressure. The present study describes the structure of bird assemblages that directly use food resources in burned areas, comparing areas affected by natural fire to the areas where controlled fires were set (a management strategy to combat arson). The tested null hypothesis was that different bird assemblages are structured in a similar manner, regardless of the post-fire period or assessed area. Between December/2012 and January/2015, 92 species were recorded foraging in the study areas. The results indicate that both types of burnings triggered profound and immediate changes in bird assemblages, increasing the number of species and individuals. Natural fires exhibited a more significant influence on the structure (diversity and dominance) than prescribed burnings. Nevertheless, all the differences were no longer noticeable after a relatively short time interval of 2-3 months after prescribed burnings and 3-4 after natural fires. The findings may help the understanding of prescribed burnings as a management strategy for bird conservation in grasslands.
\end{abstract}

Key words: Cerrado biome, diversity, environmental management, prescribed burning, wildfire.

\section{INTRODUCTION}

The Cerrado biome (Brazilian savanna) has been indicated as one of the 25 global biodiversity hotspots for priority conservation (Myers et al. 2000). However, this morphoclimatic domain continues to be fragmented and destroyed at an alarming rate (Queiroz 2014). Among the different Cerrado physiognomies, grasslands are

Correspondence to: Matheus Gonçalves dos Reis

E-mail: matheus.reis@gmail.com indicated as the most threatened type (Bond and Parr 2010). In the southern portion of the Cerrado, where less than $15 \%$ of the area is covered with native vegetation (Sano et al. 2010), the Serra da Canastra National Park (SCNP) protects the largest remaining grassland ecosystems.

Fire is a natural element in tropical grasslands and savannas. It plays a key role in these ecosystems, shaping the landscape and biotic components (Komarek 1972, Whelan 1995, Mistry 1998, Govender et al. 2006). However, arson (criminal burn- 
ing) is one of the most serious environmental problems in the Cerrado, mainly because it often occurs off-season, considering the natural fire season, and has significant impacts in terms of intensity and area affected. It is the most serious environmental threat with the greatest geographic impact that the SCNP has faced in recent decades (Medeiros and Fiedler 2004). The main management strategy applied to this protected area consists of setting planned fires in strips of vegetation (firebreaks) that serve as a barrier against acts of arson, particularly those affecting large areas (IBAMA 2005). A1though this strategy is widely used, little is known about its direct effects on birds, particularly in open grasslands.

The aim of this study is to compare the effects of natural and controlled fires in the structure of actively foraging bird assemblages in the grasslands of the SCNP. We tested the hypothesis that these assemblages are structured in a similar manner to obtain resources, regardless of the type of fire or the post-fire period.

\section{MATERIALS AND METHODS}

\section{STUDY AREA}

The SCNP is a protected area that comprises about 72,000 ha of legitimized land in a total area of approximately 200,000 ha. It includes most of the geographical landform known as the Serra $\mathrm{da} C \mathrm{Ca}$ nastra, a group of mountains that are 1200-1450 $m$ elevation and stand out from the regional landscape, which has an altitude of 700-900 m (IBAMA 2005). The park is located in the southwestern portion of the state of Minas Gerais, southeastern Brazil (Figure 1a, b).

The SCNP houses the largest remaining natural grasslands in the southern morphoclimatic and phytogeographical domain of the Cerrado. It includes physiognomies known as campos limpos (grassland), campos rupestres (rocky grassland), campos de murundus (mound grassland), campos sujos abertos (open shrub grassland), and campos úmidos (seasonally wet grassland), which are predominant in the tableland regions high in the mountains (plateau). Open savanna formations such as campo cerrado (Cerrado grassland), parque cerrado (Cerrado park) and cerrado rupestre (rocky Cerrado) are less frequent. Forest ecosystems are restricted to small natural fragments known as capões de mata (clumps of forest) and the riparian forests that line the watercourses in the tablelands on the mountaintops. In contrast, the predominant ecosystems in the valleys and low-lying areas of the region are typical Cerrado (known as Cerrado sensu stricto), cerradão (forest Cerrado), mesophilic forests, and riparian forests (Fieker et al. 2014).

The sampling sites are located in grasslands at the higher portion of the mountains, in Chapadão da Canastra plateau (central coordinates: $20^{\circ} 13$ '51.52"S 46²9'11.39”W). They were distributed where natural fires were set by lightning (wildfires), in the strips of vegetation that are regularly burned (firebreaks) as a management strategy implemented by the agency that manages SCNP, and other areas that represent the same type of environment, but have not been recently affected by fire.

\section{DATA COLLECTION}

Fieldwork was carried out from December 2012 to January 2015 through 18 separate field campaigns of 6-12 days each. This effort corresponded to 10 samples in each post-fire period ( $\left(1^{\text {st }}\right.$ to $6^{\text {th }}$ month), leading to a total of 60 samples for each of the two types of fire (natural and prescribed). Control samples $(n=60)$ were obtained in areas where at least 12 months had passed without fire.

Samples were taken at intervals of $30 \mathrm{~min}( \pm 5$ min) of slow walking, covering approximately $500 \mathrm{~m}( \pm 50 \mathrm{~m})$ length along the randomly selected transects within predefined areas. In the areas affected by natural fire, the starting points of the transects were chosen randomly from an 
area limited to 100 ha for each analyzed event, corresponding to $19.61 \%$ of the area burned in Fire A (December 2012) and 62.5\% of the area burned in Fire B (September 2013). In the firebreaks where the controlled fires took place every dry season, 25 stretches of $1 \mathrm{~km}$ were defined along approximately $50 \mathrm{~km}$ of the main road in the SCNP, where the firebreaks run parallel to the road (Figure 1c). These burned strips have an average width of $45 \mathrm{~m}( \pm 5 \mathrm{~m})$; therefore, the transects walked in the regions of natural fire were limited to sampling at fixed distances of $25 \mathrm{~m}( \pm 5 \mathrm{~m})$ on both sides, to ensure unbiased spatial patterning in all treatments (Bibby 2004). This process was repeated for the control samples, which were spread across the entire SCNP.

Only visual records of birds foraging within the defined area were noted (Sutherland 2004); nocturnal birds were excluded. During data collection, one researcher was responsible for specific records to create the list, whereas another was responsible for the visual confirmation of foraging. If foraging was not confirmed during the initial observations, the second researcher devoted approximately $180 \mathrm{~s}$ for observing each of the species, whereas the first continued to collect data along transect, maintaining the system. If at the end of the transect sampling $(30 \pm 5 \mathrm{~min}$ along $500 \pm 50 \mathrm{~m})$ any recorded species remained with unconfirmed foraging, researchers conducted a complementary search ad libitum (no obligation to follow only one direction in transect) for behavioral observations in the same sampled area, which added a maximum of $180 \mathrm{~s}$ interval focused exclusively on these species. The goal of this premise was to avoid subsampling and to ensure that all the species that directly use the sampling areas and the resources therein were recorded. Consequently, wandering individuals and species, which have less significant ecological interactions within the ecosystem, were excluded. If there were doubts about foraging behavior, the record was discarded.

\section{DATA ANALYSIS}

The treatments corresponded to the two types of fires (natural or controlled) in six post-fire periods, from the $1^{\text {st }}$ to the $6^{\text {th }}$ month, counting from the date the fire was extinguished. Areas with no record of fire for at least 12 months were considered control samples. For monthly comparisons between each one of the treatments and the control, $\mathrm{n}=10$ samples were randomly selected from the 60 control samples. This random selection was repeated for each comparison to ensure randomness of the spatial and temporal patterns (Bibby 2004).

The set of natural fire samples originated from two climatic events characterized by lightning storms, that occurred in December (2012) and September (2013). Seasonal ecological differences could compromise the temporal analysis of the post-fire periods as well as the efforts to standardize sampling. Therefore, the differences between each pair of post-fire periods ( $\mathrm{n}=6$ pairs) were tested by the same method used to ascertain the central hypothesis. Because there were no significant differences, it was concluded that there were no seasonal influences and that the community's structure was similar between the months. Based on this observation, it was possible to combine monthly samples of each event $(n=5)$, so that the pattern of $n=10$ samples for each month after the fire could be maintained. The regular periodicity of the prescribed (or controlled) fires ensured temporal patterning in this group of samples.

An assemblage can be defined as a set of phylogenetically-related species that coexist in a given space at a specific time (Fauth et al. 1996). This definition supports the following procedures. The Shannon diversity index (H') and the dominance index $(\mathrm{D}=1$ - Simpson's evenness index) were chosen to describe the organization of the assemblages of birds. More details on the calculation of these extensively used indexes can be found in Magurran (2004) and Zar (1999). The 


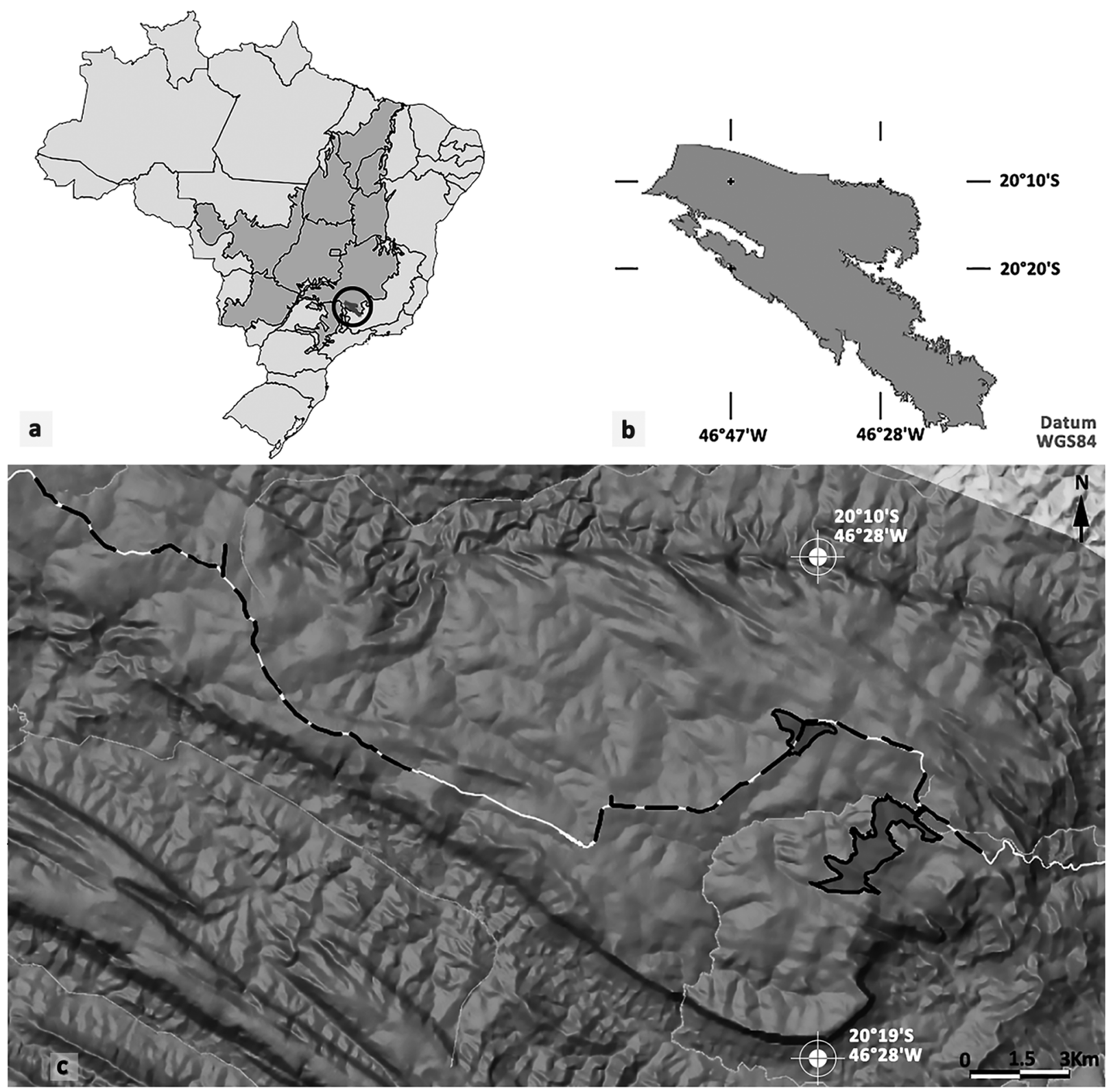

Figure 1 - Location of the study area. (a) Political map of Brazil, with the Cerrado biome highlighted. The circle in southern Cerrado indicates the location of the Serra da Canastra National Park (SCNP). (b) Area of SCNP (200,000 ha) with geographical coordinates. (c) Map of the sampling sites. The black lines are 25 transects of $1 \mathrm{Km}$ length where prescribed burnings were annually set. The two areas of irregular shape indicate the limits of natural fires that occurred in December 2012 (the largest) and September 2013.

values obtained for each index were compared with the minimum and maximum limits obtained in 10,000 bootstrap resamplings with a $95 \%$ confidence interval (Hammer 2015) in search of disparities. All values were in line with the expectations. The relative abundance corresponds to the percentage of records for that species in relation to the total number of records in the sample considered (monthly or total).

Data normality was confirmed by the ShapiroWilk test using Bioestat 5.3 software (Ayres et al. 2007). Other tests were run using PAST software 
(Hammer et al. 2001) version 3.05 from January 2015. Statistical comparisons between each assemblage were performed using the t-test adapted to the Shannon diversity index and Simpson's evenness index (Magurran 2004). To create the list, the taxonomic hierarchy and nomenclature for the species observed in the field followed the standards adopted by the Brazilian Ornithological Records Committee (CBRO 2014).

\section{RESULTS}

During the entire study period, 92 birds were observed in foraging activities. The list of species presented in the Appendix SI - Supplementary Material provides information on the relative abundance for each bird in the various post-fire periods and for each type of fire, as well as the data for the control samples. Eighty species of birds have been recorded foraging in areas affected by natural fire, whereas 61 birds were recorded in prescribed fire areas from the initial days up to six months after each event. In areas where fire did not occur for at least 12 months (control samples), a total of 85 species were observed. Despite the highest overall richness, the control areas exhibited a lower monthly richness.

Figure 2 shows the total number of species and individuals recorded in each post-fire period, and the monthly average of control samples. Both types of fire caused immediate changes that increased the bird richness and number of individuals. However, these numbers decreased with time. After 3 months in areas of prescribed fires and 4 months after natural fires, the richness and abundance became more similar to non-burned areas, where the mean monthly richness were $43.83( \pm 8.3)$ bird species and $266.5( \pm 44.7)$ individuals (Figure 2$)$.

According to the results showed in Table I, there were significant differences between the structure of the assemblages for each type of fire as well as between these and the control samples in the first months $(\mathrm{p}<0.05)$. These differences became undetectable over time $(\mathrm{p}>0.05)$, considering the post-fire treatments. Therefore, we accept the alternative hypothesis that the assemblages of foraging birds in the grasslands are structured differently according to the type of fire and postfire period.

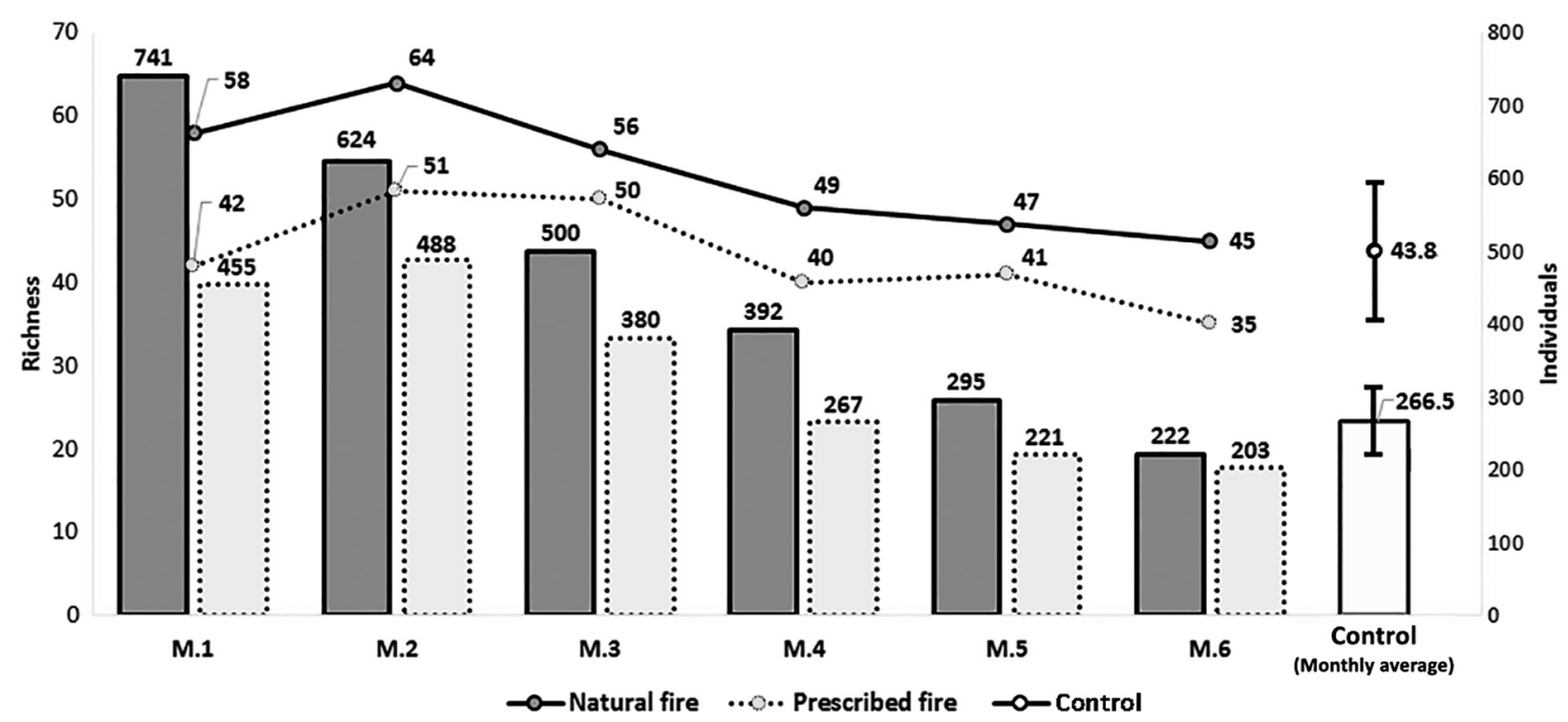

Figure 2 - Species richness (line) and number of individuals (columns) recorded for each type of fire (natural and prescribed) over 6 months after burnings (M.1 to M.6), and the monthly average and standard deviation of control samples. 
TABLE I

Diversity t-test results. M.1 to M.6 = sampled months after the fire. $H^{\prime}=$ diversity index. $D=$ dominance. Statistically significant results are highlighted.

\begin{tabular}{|c|c|c|c|c|c|}
\hline $\begin{array}{l}\text { Post-fire } \\
\text { month }\end{array}$ & Natural fire & $\begin{array}{l}\text { Prescribed } \\
\quad \text { fire }\end{array}$ & $\begin{array}{c}\text { Natural fire } \\
\mathrm{X} \\
\text { Prescribed fire }\end{array}$ & $\begin{array}{c}\text { Natural fire } \\
\mathbf{X} \\
\text { Control }\end{array}$ & $\begin{array}{c}\text { Prescribed fire } \\
\mathbf{X} \\
\text { Control }\end{array}$ \\
\hline \multirow{2}{*}{ M.1 } & $\mathrm{H}^{\prime}=3.498$ & $\mathrm{H}^{\prime}=3.257$ & $\begin{array}{l}\mathrm{t}=4.2 ; \mathrm{df}=967.05 \\
\mathbf{p}=\mathbf{0 . 0 0 0 3}\end{array}$ & $\begin{array}{l}\mathrm{t}=4.14 ; \mathrm{df}=360.64 \\
\mathbf{p}=\mathbf{0 . 0 0 0 4}\end{array}$ & $\begin{array}{l}\mathrm{t}=3.57 ; \mathrm{df}=643.02 ; \\
\mathbf{p}=\mathbf{0 . 0 0 0 4}\end{array}$ \\
\hline & $\mathrm{D}=0.0427$ & $\mathrm{D}=0.0548$ & $\begin{array}{l}\mathrm{t}=-2.7 ; \mathrm{df}=785.8 \\
\mathbf{p}=\mathbf{0 . 0 0 7}\end{array}$ & $\begin{array}{l}t=-2.46 ; \mathrm{df}=289.6 \\
\mathbf{p}=\mathbf{0 . 0 1 5}\end{array}$ & $\begin{array}{l}t=-1.54 ; \mathrm{df}=721.7 \\
\mathrm{p}=0.12\end{array}$ \\
\hline \multirow{2}{*}{ М.2 } & $\mathrm{H}^{\prime}=3.672$ & $\mathrm{H}^{\prime}=3.454$ & $\begin{array}{l}\mathrm{t}=3.72 ; \mathrm{df}=1044.3 \\
\mathbf{p}=\mathbf{0 . 0 0 0 2}\end{array}$ & $\begin{array}{l}\mathrm{t}=3.72 ; \mathrm{df}=481.93 \\
\mathbf{p}=\mathbf{0 . 0 0 0 2}\end{array}$ & $\begin{array}{l}\mathrm{t}=3.34 ; \mathrm{df}=427.88 ; \\
\mathbf{p}=\mathbf{0 . 0 0 9}\end{array}$ \\
\hline & $\mathrm{D}=0.0366$ & $\mathrm{D}=0.0468$ & $\begin{array}{l}\mathrm{t}=-2.38 ; \mathrm{df}=844.5 \\
\mathbf{p}=\mathbf{0 . 0 1 7}\end{array}$ & $\begin{array}{l}\mathrm{t}=-3.04 ; \mathrm{df}=365.6 \\
\mathbf{p}=\mathbf{0 . 0 0 2}\end{array}$ & $\begin{array}{l}t=-1.66 ; d f=392.2 \\
p=0.10\end{array}$ \\
\hline \multirow{2}{*}{ M.3 } & $\mathrm{H}^{\prime}=3.48$ & $\mathrm{H}^{\prime}=3.321$ & $\begin{array}{l}\mathrm{t}=2.15 ; \mathrm{df}=771 \\
\mathbf{p}=\mathbf{0 . 0 3 2}\end{array}$ & $\begin{array}{l}\mathrm{t}=3.63 ; \mathrm{df}=444.03 \\
\mathbf{p}=\mathbf{0 . 0 0 0 3}\end{array}$ & $\begin{array}{l}\mathrm{t}=1.49 ; \mathrm{df}=520.13 ; \\
\mathrm{p}=0.14\end{array}$ \\
\hline & $\mathrm{D}=0.0461$ & $\mathrm{D}=0.0614$ & $\begin{array}{l}\mathrm{t}=-2.19 ; \mathrm{df}=588 \\
\mathbf{p}=\mathbf{0 . 0 2 9}\end{array}$ & $\begin{array}{l}\mathrm{t}=-1.81 ; \mathrm{df}=360.8 \\
\mathrm{p}=0.07\end{array}$ & $\begin{array}{l}t=-0.36 ; d f=569.6 ; \\
p=0.72\end{array}$ \\
\hline \multirow{2}{*}{ M.4 } & $\mathrm{H}^{\prime}=3.331$ & $\mathrm{H}^{\prime}=3.258$ & $\begin{array}{l}t=0.96 ; d f=600.3 \\
p=0.33\end{array}$ & $\begin{array}{l}\mathrm{t}=1.84 ; \mathrm{df}=531.62 \\
\mathrm{p}=0.07\end{array}$ & $\begin{array}{l}t=0.82 ; d f=487.79 ; \\
p=0.41\end{array}$ \\
\hline & $\mathrm{D}=0.0515$ & $\mathrm{D}=0.0535$ & $\begin{array}{l}\mathrm{t}=-0.31 ; \mathrm{df}=552.8 \\
\mathrm{p}=0.75\end{array}$ & $\begin{array}{l}\mathrm{t}=-0.27 ; \mathrm{df}=514.59 \\
\mathrm{p}=0.79\end{array}$ & $\begin{array}{l}\mathrm{t}=-0.05 ; \mathrm{df}=491 \\
\mathrm{p}=0.96\end{array}$ \\
\hline \multirow{2}{*}{ M.5 } & $\mathrm{H}^{\prime}=3.435$ & $\mathrm{H}^{\prime}=3.31$ & $\begin{array}{l}t=1.56 ; d f=453.5 \\
p=0.12\end{array}$ & $\begin{array}{l}\mathrm{t}=0.01 ; \mathrm{df}=553.54 \\
\mathrm{p}=0.99\end{array}$ & $\begin{array}{l}\mathrm{t}=1.34 ; \mathrm{df}=523.28 ; \\
\mathrm{p}=0.18\end{array}$ \\
\hline & $\mathrm{D}=0.0415$ & $\mathrm{D}=0.0513$ & $\begin{array}{l}\mathrm{t}=-1.57 ; \mathrm{df}=358 \\
\mathrm{p}=0.11\end{array}$ & $\begin{array}{l}\mathrm{t}=-2.37 ; \mathrm{df}=407.5 \\
\mathbf{p}=\mathbf{0 . 0 1 7}\end{array}$ & $\begin{array}{l}t=-0.99 ; d f=516.5 ; \\
p=0.32\end{array}$ \\
\hline \multirow{2}{*}{ M.6 } & $\mathrm{H}^{\prime}=3.378$ & $\mathrm{H}^{\prime}=3.248$ & $\begin{array}{l}\mathrm{t}=1.52 ; \mathrm{df}=424.9 \\
\mathrm{p}=0.13\end{array}$ & $\begin{array}{l}\mathrm{t}=0.89 ; \mathrm{df}=445.81 \\
\mathrm{p}=0.37\end{array}$ & $\begin{array}{l}t=-0.69 ; d f=423.4 \\
p=0.49\end{array}$ \\
\hline & $\mathrm{D}=0.0462$ & $\mathrm{D}=0.0513$ & $\begin{array}{l}\mathrm{t}=-1.0 ; \mathrm{df}=405.1 \\
\mathrm{p}=0.44\end{array}$ & $\begin{array}{l}\mathrm{t}=-0.85 ; \mathrm{df}=449.9 \\
\mathrm{p}=0.39\end{array}$ & $\begin{array}{l}t=-0.26 ; d f=413.5 ; \\
p=0.79\end{array}$ \\
\hline
\end{tabular}

The results presented in Table I indicate that the structure of assemblages in areas affected by natural fire is distinct from prescribed fire areas from the first to the third month after each fire event. The diversity index $\mathrm{H}^{\prime}$ is higher, whereas the dominance index D is smaller in areas subjected to natural fires. The same result was observed when natural fire areas were compared to control areas, with the exception of dominance, which showed no difference in the third month but showed in the fifth. After the fourth month, there were no significant differences in the H' index in any comparison between the treatments (Table I).

The structure of assemblages that foraged in the prescribed fire areas differed from the control samples only in the first 2 post-fire months. Particularly, the difference was visible in the H' index. There were no differences between the values for $\mathrm{D}$ index during the six months after the fire (Table I).

\section{DISCUSSION}

The 92 observed species with confirmation of foraging activity in natural grasslands represent $22.8 \%$ of the 403 birds found in all of the Serra da Canastra region's ecosystems and surrounding area, inside and outside the boundaries of the National Park (Bessa et al. 2011).

Because of the spatial limitations of the sampling areas, some species that are known to directly use the resources from the open grasslands could not be recorded. For example, Falco sparverius and Urubitinga coronatus are resident species in the grasslands of SCNP that were not 
recorded feeding during the systematic data collection. Furthermore, although their feeding activities began at the end of daylight during the sampling period, nocturnal birds that feed in the study areas were excluded, as was the case with Hydropsalis longirostris and Chordeiles pusillus.

The low abundance observed in a considerable number of species, besides being expected in natural biological communities (Stirling and Wilsey 2001), or even a reflection of the sampling limitation for certain birds (Bibby et al. 2000), could also indicate the avoidance response of some species to a particular treatment. This may be due to the unavailability of preferred resources or behavioral restrictions on habitat structure. It is also important to remember that some species recorded in low abundance are characteristics of other environments such as forests and the banks of water courses. These records were considered to be opportunistic behavior, unusual within the behavioral repertoire and characterized by individuals who have ventured into open grasslands in search of specific opportunities to obtain food. Individuals of Turdus leucomelas and Tangara cayana, species which are recognized as generalists (Sick 1997), came out of gallery forests, flew to areas where resources were present, covering distances that easily exceeded $50 \mathrm{~m}$, fed and returned to their preferred environments. Both species were recorded feeding outside the breeding season and also carrying food to their chicks in November and December. However, the records of Scytalopus novacapitalis were unexpected because the species is highly dependent on low-light forest habitats (Sick 1997). The five sightings occurred on the edge of the sampling area, no more than 2 $\mathrm{m}$ from the forest. The individuals were always moving between very shaded or dark places on the ground amidst the densest clusters of grasses and partially burned vegetation. The sighting of Gallinago undulata, a wading bird, occurred on the edges of some sampling areas in grasslands that flooded after a month of intense rain, near a watercourse.

Species richness was significantly higher in the first post-fire months, as was the number of recorded individuals. Although the prescribed burnings attracted fewer species in lower abundance than the natural fire, both types of fires exhibited greater richness and abundance when compared with the same number of control area samples. A similar pattern was found for the Shannon diversity index and Simpson's dominance index, which indicates that newly-burned areas are highly attractive and have higher immediate support capacity than areas unaffected by fire or the same areas after 3-4 months.

The control area, which was considered not to be under the influence of fire, presented higher richness, as per the collected 60 samples. However, the other descriptors for the structure of the biological communities were comparatively lower. Even the average species richness recorded in each set of 10 randomly-selected control samples was always lower than that in each set of 10 samples from the six post-fire periods for the two types of fire. This probably occurred because some species are not able to occupy burned areas; however, it is expected that all grassland species use unburned areas, even when they exhibit ecological dependence upon fire. Therefore, all possible species would be recorded in the unburned areas over time, whereas in areas affected by fire, the addition of species would reach a limit.

These results are consistent with the idea that changes in the availability of resources in specific places and times, also known as the "resource pulse", extend feeding opportunities and cause profound changes in the composition and abundance of biological communities while this situation is maintained (Yang et al. 2008). In fact, in the newly burned areas, there were numerous recordings of feeding opportunities for birds, including larger reptiles (in comparison with the 
size of the birds, e.g. Philodryas sp.; Oxyrhopus sp.), amphibians (e.g. Bokermannohyla sp.; Scinax sp.), small mammals (e.g. Bolomys sp., Thricomys apareoides), arthropods, and mushrooms. Even the mineral components were utilized as resource, when psittacines ingested the outside portion of termite nests (Insecta: Isoptera) which were burned by the flames coming from the surrounding tall grasses. Another example is the variation in the abundance of raptors (Accipitridae and Falconidae). These birds are strongly attracted to newly-burned areas (Sick 1997), whereas their abundance returns to expected levels (typically low) in the subsequent months, the same levels found in areas with no fire for more than a year.

In general, few articles have been published on the effects of fire on birds in Brazil's grasslands and open savannas (Mistry 1998, Frizzo et al. 2011). Majority of the studies conducted in grassland ecosystems in Brazil (e.g. Cavalcanti and Alves 1997, Cintra and Sanaiotti 2005, Sendoda 2009) and in other countries (e.g. Skowno and Bond 2003, Fuhlendorf et al. 2006, Gregory et al. 2010) have indicated changes in the assemblages of birds, suggesting that the vegetation structure and availability of food resources are the main environmental components that may explain the differences before and after fire.

Cavalcanti and Alves (1997) evaluated the effect of fire on birds in an area of Cerrado sensu stricto. Their results indicated that individuals that had been observed and identified with rings before the fire, they went back, remaining faithful to the area after the fire. Some of the species only modified their foraging strategy, probably owing to changes in the structure of the vegetation after the fire. Only one additional species (Charitospiza eucosma) was recorded after the fire and was considered by the authors as colonizing species and fire specialist. In the present study, we also registered a species that can be considered a specialist and a post-fire colonizer, Geositta poeciloptera (Parker and Willis
1997); in this study, the abundance of this species increased markedly in newly-burned areas. This could be because the holes that were abandoned by other animals such as small rodents and armadillos, which these birds use for their nests, are more exposed after fire consumes the vegetation, as is their prey (arthropods). In recently burned shrub grasslands in the Chapada dos Veadeiros National Park, G. poeciloptera also had higher sighting rates (Braz 2008).

Cintra and Sanaiotti (2005) found that the composition of bird communities 2 months before the fire differed significantly from two months after the fire, in an Amazonian savanna in Alterdo-Chão, state of Pará. These results are similar to the findings in the first months of the present study on richness and diversity of birds. Specifically, this effect was more evident when areas of natural fire events were compared to control areas. Petry et al. (2011) reported a similar pattern in grassland formations within the Atlantic Forest biome, in Rio Grande do Sul state.

Pacheco et al. (1994) compared the abundance of three tinamids (Rynchotus rufescens, Nothura maculosa, and Crypturellus parvirostris) in unburned and burned Cerrado areas and found lower abundance in the latter up to 10 months after fire. Conversely, in the present study, we observed a higher abundance of $R$. rufescens and N. maculosa in natural and prescribed fire areas compared to the control areas.

Considering species and ecosystem conservation, this study contributes with relevant information on the use of controlled fires to create firebreaks as a conservation strategy. It is important to point out that although these ecosystems are naturally dependent upon fire, very frequent arson directly impacts the Serra da Canastra grasslands, as do fires set on private properties in the surrounding area that get out of control (IBAMA 2005). Several studies describe the ecological problems caused by changes in the fire regime, in its frequency, inten- 
sity, and season of occurrence, mainly with regard to vegetation (e.g. Sanaiotti and Magnusson 1995, Hoffmann 1996, Fidelis et al. 2010). In the present study, the following characteristics were notable in areas affected by planned fires: (i) the impacts were very limited in time, (ii) the affected area recovered more quickly than the area affected by natural fire, (iii) some parameters for assemblages were identical to those of areas unaffected by fire. Moreover, the birds recorded in this study, which included several threatened species, (iv) made direct use of the resources provided by the firebreak areas, indicating that the process of setting prescribed fire, just as natural fire, offers feeding opportunities for a large number of species. Because they occur in low-rainfall periods (winter), it is possible that prescribed fires create areas with greater availability of certain food resources that are very important for some populations, particularly migratory birds such as the Seedeaters (Sporophila spp.), recorded in this study. This effect is due to the stimulating influence of fire on the flowering and fruiting of various grasses (Parron and Hay 1997, Miranda et al. 2009), producing seeds that are a fundamental part of the diet of these birds.

The Serra da Canastra National Park is an Important Bird Area (IBA) (Bencke et al. 2006) with significant bio-geographic relevance for the entire southern Cerrado region. Considering this and the fact that 13 species, $14.13 \%$ of all species recorded in the present study are listed in some category on the IUCN Red List (2014), our results suggest that more efforts should be invested in the conservation of the SCNP, focusing on the problems caused by arson.

\section{ACKNOWLEDGMENTS}

We thank Conselho Nacional de Desenvolvimento Científico e Tecnológico (CNPq) for the scholarship granted to M.G. Reis (this article is a part of his thesis), and Coordenação de Aperfeiçoamento de Pessoal de Nível Superior (CAPES) for the scholarship granted to C.Z. Fieker. We thank the Programa de Pós-Graduação em Ecologia e Recursos Naturais (PPG-ERN) of the Universidade Federal de São Carlos (UFSCar). Our thanks to external referees of the journal, and to A.Z. Antunes, M. Telles, M.R. Francisco, M.A. Fernandes, S. Buck, A.L.T. Souza and O. Rocha for the helpful comments and suggestions. We are grateful to the Serra da Canastra National Park staff for the assistance and ICMBio for the authorizations to develop research and for the field support. We thank Crimson Interactive (Ulatus) for their assistance in manuscript translation.

\section{RESUMO}

Os campos abertos são as fisionomias mais ameaçadas do bioma Cerrado (savana brasileira), um hotspot de biodiversidade com prioridade de conservação. O Parque Nacional da Serra da Canastra protege os mais importantes remanescentes de campos abertos da região sul do Cerrado, a qual se encontra sob forte pressão antropogênica. O presente estudo descreve a estrutura das assembleias de aves que fazem uso direto de recursos alimentares em áreas queimadas, comparando áreas atingidas por fogo natural às áreas onde foram realizadas queimadas planejadas (estratégia de manejo contra incêndios criminosos). Foi testada a hipótese nula de que as diferentes assembleias de aves se estruturam de maneira similar, independente do período do pós-fogo ou da área estudada. Entre dezembro de 2012 e janeiro de 2015, foram registradas um total de 92 espécies de aves forrageando nas áreas de estudo. Os resultados indicam que ambos os tipos de queimadas provocaram mudanças profundas e imediatas nas assembleias de aves, aumentando o número de espécies e indivíduos. Queimadas naturais exibiram uma influência mais significativa na estrutura (diversidade e dominância) do que queimadas prescritas. Mesmo assim, as diferenças passaram a não ser mais detectadas após um período relativamente curto de $2-3$ meses após queimadas prescritas e de $3-4$ meses após o fogo natural. Os resultados podem contribuir para a compreensão das queimadas prescritas como estratégia de manejo para a conservação de aves em ambientes campestres. 
Palavras-chave: Bioma Cerrado, diversidade, manejo ambiental, queimada planejada, fogo natural.

\section{REFERENCES}

AYRES M, AYRES JRM, AYRES DL AND SANTOS AS. 2007. BioEstat 5.3 - Aplicações Estatísticas nas Áreas das Ciências Biológicas e Médicas. Belém: Instituto de Desenvolvimento Sustentável de Mamirauá; CNPq, 364 p.

BENCKE GA, MAURÍcIO GN, DEVELEY PF AND GOERCK JM. 2006. Áreas importantes para a conservação das Aves no Brasil. Parte I - Estados do Domínio da Mata Atlântica. Brasil: Editora SAVE Brasil, 494 p.

Bessa R, PARrini R, ABDala A, KirWan GM, PIMENTEl LSM AND BRUNO SF. 2011. Novos registros ornitológicos para a região da Serra da Canastra, Minas Gerais, Brasil. Cotinga 33: 94-101.

BIBBY CJ. 2004. Bird diversity survey methods. In: Sutherland WJ, Newton I and Green RE (Eds), Bird ecology and conservation: a handbook of techniques. Oxford University Press, p. 1-15.

BibBy CJ, Burgess ND, Hill DA AND Mustoe SH. 2000. Bird census techniques. $2^{\text {nd }}$ ed., Academic Press, USA, $302 \mathrm{p}$.

BOND WJ AND PARR CL. 2010. Beyond the forest edge: Ecology, diversity and conservation of the grassy biomes. Biol Conserv 143(10): 2395-2404.

BRAZ VS. 2008. Ecologia e conservação das aves campestres do bioma Cerrado. Thesis, Instituto de Ciências Biológicas, Universidade de Brasília, 178 p.

CAVAlCANTI RB AND ALVES MAS. 1997. Effects of fire on savanna birds in central Brazil. Ornitol Neotrop 8(1): 85-87.

CBRO - COMITÊ BRASILEIRO DE REGISTROS ORNITOLÓGICOS. 2014. Listas das aves do Brasil. $11^{\text {a }}$ Edição, 41 p.

CinTRA R AND SANAiOTTI TM. 2005. Fire effects on the composition of a bird community in an Amazonian Savanna (Brazil). Braz J Biol 65(4): 683-695.

FAUTH JE, BERNARDO J, CAMARA M, RESETARITS WJ, VAN BUSKIRK J AND MCCOLLUM SA. 1996. Simplifying the jargon of community ecology: a conceptual approach. Am Nat 147(2): 282-286.

Fidelis A, DELGADO-CARTAY MD, Blanco CC, MÜLler SC, PILlar VD AND PFADENHAUER J. 2010. Fire intensity and severity in Brazilian Campos grasslands. Interciencia 35(10): 739-745.

FIEKER CZ, REIS MG AND BRUNO SF. 2014. Guia de bolso: 100 aves do Parque Nacional da Serra da Canastra - MG. São Roque de Minas: ICMBio, 124 p.

FRIZZO TL, BONIZARIO C, BORGES MP AND VASCONCELOS H. 2011. Uma revisão dos efeitos do fogo sobre a fauna de formações savânicas do Brasil. Oecol Aust 15(2): 365-379.

FUHLENDORF SD, HARRELL WC, ENGLE DM, HAMILTON RG, DAVIS CA AND LESLIE JR DM. 2006. Should het- erogeneity be the basis for conservation? Grassland bird response to fire and grazing. Ecol Appl 16(5): 1706-1716.

Govender N, TROLlope WSW AND VAN WILGEN BW. 2006. The effect of fire season, fire frequency, rainfall and management on fire intensity in savanna vegetation in South Africa. J Appl Ecol 43(4): 748-758.

GREGORY NC, SENSENIG RL AND WILCOVE DS. 2010. Effects of controlled fire and livestock grazing on bird communities in East African savannas. Conserv Biol 24(6): 1606-1616.

HAMMER Ø. 2015. PAST - Paleontological Statistics Reference Manual, v.3.05. Oslo: Natural History Museum, University of Oslo, $224 \mathrm{p}$.

HAMMER Ø, HARPER DAT AND RYAN PD. 2001. PAST: Paleontological Statistics Software Package for Education and Data Analysis. Palaeontol Electron 4(1): 1-9.

HOFFMANN WA. 1996. The Effects of Fire and Cover on Seedling Establishment in a Neotropical Savanna. J Ecol 84(3): 383-393.

IBAMA. 2005. Parque Nacional da Serra da Canastra: Plano de Manejo. Brasília: Ministério do Meio Ambiente/ IBAMA, 828 p.

IUCN - INTERNATIONAL UNION FOR CONSERVATION OF NATURE. 2014. The IUCN Red List of Threatened Species. Version 2014.3.

KOMAREK EV. 1972. Lightning and fire ecology in Africa. Proceedings Third Annual Tall Timbers Fire Ecology Conference, p. 483-511.

MAGURRAN AE. 2004. Measuring biological diversity. Blackwell Publishing: Oxford, UK, 256 p.

MEDEIROS MB AND FIEDLER NC. 2004. Incêndios florestais no Parque Nacional da Serra da Canastra: desafios para a conservação da biodiversidade. Ciênc Florest 14(2): 157168.

Miranda HS, SATo MN, Neto WN AND Airs FS. 2009. Fires in the Cerrado, the Brazilian Savana. In: Cochrane MA (Ed), Tropical Fire Ecology - Climate change, Land use and Ecosystems Dynamics. New York: Springer, 622 p.

MISTRY J. 1998. Fire in the cerrado (savannas) of Brazil: an ecological review. Prog Phys Geog 22(4): 425-448.

MYERS N, MitTERMEIER RA, MitTERMEIER CG, FONSECA GA AND KENT J. 2000. Biodiversity hotspots for conservation priorities. Nature 403(6772): 853-858.

PACHECO S, RIBON R, SILVA NF, SIMON JE AND PINHEIRO RT. 1994. Efeito do manejo do cerrado sobre as populações de alguns Tinamidae em Três Marias, Estado de Minas Gerais. Rev Bras Biol 54: 435-441.

PARKER III TA AND WILLIS EO. 1997. Notes on three tiny grassland flycatchers, with comments on the disappearance of South American fire-diversified savannas. Ornithol Monogr 48: 549-555. 
PARRON LM AND HAY JD. 1997. Effect of fire on seed production of tow native grasses in the Brazilian Cerrado. Ecotropicos 10: 1-8.

PETRY MV, PIUCO RC AND BRUMMELHAUS J. 2011. Aves associadas ao manejo com fogo em áreas de Campo na porção sul do Bioma Mata Atlântica. Bio Brasil 2: 110-119.

QUEIROZ FA. 2014. International trade and environment: impacts of the export-driven soybean production on the biodiversity of the Brazilian Cerrado (1960-2005). J Int Bus Econ 2(1): 11-28.

SANAIOTTI TM AND MAGNUSSON WE. 1995. Effects of annual fire on the production of fleshy fruits eaten by birds in a Brazilian Amazonian savanna. J Trop Ecol 11(1): 53-65.

SANO EE, ROSA R, BRITO JL AND FERREIRA LG. 2010. Land cover mapping of the tropical savanna region in Brazil. Environ Monit Assess 166(1): 113-124.

SENDODA AMC. 2009. Efeitos do manejo do fogo sobre comunidades de aves em campos sujos no Parque Nacional das Emas (GO/MS), Cerrado central. Dissertation, Instituto de Biociências, Universidade de São Paulo, 63 p. (Unpublished).

SICK H. 1997. Ornitologia Brasileira. (Edição revista e ampliada por PACHECO JF 2001). Rio de Janeiro: Editora Nova Fronteira, 912 p.

SKOWNO AL AND BOND WJ. 2003. Bird community composition in an actively managed savanna reserve, importance of vegetation structure and vegetation composition. Biodivers Conserv 12: 2279-2294.
STIRLING G AND WILSEY B. 2001. Empirical relationships between species richness, evenness, and proportional diversity. Am Nat 158(3): 286-299.

SUTHERLAND WJ. 2004. Diet and foraging behaviour. In: Sutherland WJ, Newton I and Green RE (Eds), Bird ecology and conservation: a handbook of techniques. Oxford University Press, p. 233-250.

WHELAN RJ. 1995. The ecology of fire. Cambridge University Press, Cambridge, 346 p.

YANG LH, BASTOW JL, SPENCE KO AND WRIGHT AN. 2008. What we can learn from resource pulses? Ecology 89(3): 631-634.

ZAR JH. 1999. Biostatistical Analysis. Upper Saddle River, New Jersey: Prentice Hall, 663 p.

\section{SUPPLEMENTARY MATERIAL}

Appendix SI - List of birds recorded foraging in grasslands of the Serra da Canastra National Park. The values correspond to relative abundance and are presented as the percentage (\%) of total records for each assemblage. 1-6 = post-fire periods in months. Ctrl $=$ control samples. $*=$ Species in IUCN (2014) Global Red List, VU = vulnerable, NT $=$ near threatened. 